\title{
Pengaruh Model Self Regulated Learning terhadap Hasil Belajar Fisika Siswa SMP Negeri 18 Palu
}

\author{
Sitti Rabia, Syamsu dan Muslimin \\ biarabia028@gmail.com \\ Program Studi Pendidikan Fisika FKIP Universitas Tadulako \\ Jl. Soekarno Hatta Km. 9 Kampus Bumi Tadulako Tondo Palu - Sulawesi Tengah
}

\begin{abstract}
Abstrak - Penelitian ini bertujuan untuk mengetahui perbedaan hasil belajar fisika antara siswa yang mengikuti model Self Regulated Learning dan siswa yang mengikuti pembelajaran konvensional di kelas VIII SMP Negeri 18 Palu. Metode yang digunakan adalah eksperimen kuasi dengan equivalent preetest-posttest design. Populasi penelitian ini adalah seluruh siswa kelas VIII SMP Negeri 18 Palu. Teknik pengambilan sampel adalah purposive sampling. Kelas VIII B sebagai kelas kontrol dan kelas VIII A sebagai kelas eksperimen. Instrumen hasil belajar fisika siswa adalah tes pilihan ganda yang telah divalidasi oleh validator dan telah di uji validitas item. Hasil analisa data diperoleh skor rata-rata kelas eksperimen 13,30 dengan standar deviasi 3,47 dan kelas kontrol 10,50 dengan standar deviasi 3,00 dari jumlah skor total yaitu 22 skor. Berdasarkan uji hipotesis diperoleh $t_{\text {hitung }}>t_{\text {tabel }}=2,84>2,02$. Maka $\mathrm{H}_{1}$ diterima dan $\mathrm{H}_{0}$ ditolak. Sehingga dapat disimpulkan bahwa terdapat perbedaan hasil belajar fisika antara kelas yang mengikuti model Self Regulated Learning dengan model pembelajaran konvensional.
\end{abstract}

Kata Kunci: Self Regulated Learning, Hasil Belajar Fisika.

\section{PENDAHULUAN}

Pembelajaran mempunyai peran penting dalam proses pendidikan, keberhasilan suatu pendidikan diawali dengan bagaimana pembelajaran dilakukan, karena disitulah seorang guru dapat mengetahui sejauh mana siswanya memahami materi yang disampaikan. Dalam rangka mencapai tujuan pendidikan, maka pembelajaran harus disesuaikan dengan kebutuhan yang ingin dicapai. Dalam hal ini, peran pendidik sangat berperan penting dalam merencanakan dan mengelola lingkungan belajar sehingga dalam proses belajar tersebut siswa dapat menunjukkan perubahan atau perkembangan tingkah laku sebagaimana yang diharapkan.

Ilmu fisika merupakan ilmu yang bersifat empiris, artinya setiap hal yang dipelajari dalam fisika didasarkan pada hasil pengamatan tentang gejala alam. Dengan adanya pelajaran fisika di sekolah, siswa dapat mengembangkan kemampuan melalui latihan bertindak atas dasar pemikiran yang logis, rasional dan cermat [1].

Proses belajar mengajar guru sebagai pengajar dan siswa sebagai subjek belajar dituntut adanya perubahan di dalam pengetahuan, kemampuan, nilai sikap serta sifat-sifat pribadi agar proses belajar dan pembelajaran dapat efektif dan efesien. Masalah kurang berminatnya siswa terhadap mata pelajaran fisika, dan kurangnya tingkat kemampuan berfikir siswa, membuat para guru fisika harus berusaha keras untuk mencari solusi dari tiap masalah yang muncul, adanya solusi ini diharapkan proses pembelajaran dapat berjalan dengan baik, dan memperoleh hasil sesuai dengan tujuan yang hendak dicapai.

Rendahnya hasil belajar fisika yang dicapai siswa dipengaruhi oleh banyak faktor, baik berasal dari dalam diri siswa maupun faktor yang berasal dari luar diri siswa. Penggunaan model atau metode pembelajaran merupakan salah satu faktor yang mempengaruhi hasil belajar siswa [2].

Metode mengajar guru yang kurang baik akan mempengaruhi hasil belajar siswa sehingga model atau metode mengajar yang digunakan harus tepat, efisien dan efektif.

Model pembelajaran Self Regulated Learning ini melibatkan aspek motivasi dalam belajar, berupa pengarahan perilaku untuk mencapai kegiatan belajar. Siswa yang melibatkan aspek motivasi dalam melaksanakan kegiatan belajarnya ini lebih cenderung untuk bersikap mandiri dalam melaksanakan kegiatan belajar dan lebih bertanggung jawab terhadap kegiatan belajarnya karena mereka menyadari bahwa hanya atas usaha mereka sendirilah tujuan belajar mereka dapat dicapai dan untuk mencapai tujuan belajar tersebut mereka harus mempunyai dan menumbuhkan motivasi yang kuat agar dapat mencapai target yang diharapkan, karena dalam proses belajar, motivasi sangat diperlukan, sebab seseorang yang tidak mempunyai motivasi dalam belajar,tidak akan mungkin dapat melakukan aktivitas atau kegiatan belajar sehingga tidak sampai pada tujuan dari belajar itu sendiri [3].

Dalam model pembelajaran Self Regulated Learning ini siswa dituntut untuk mampu mempunyai dan menumbuhkan motivasi dalam diri siswa itu sendiri untuk dapat melaksanakan 
kegiatan belajar serta untuk mencapai tujuan belajar yang telah [4].

Pembelajaran konvensional adalah pembelajaran tradisional, karena sejak dulu pembelajaran ini telah dipergunakan sebagai alat komunikasi lisan antara guru dan anak didik dalam proses belajar dan pembelajaran [5].

Pembelajaran konvensional yang diterapkan di SMP Negeri 18 Palu yaitu model Direct Instruction (DI) atau model pembelajaran langsung. Model pembelajaran langsung adalah model pembelajaran yang menekankan pada penguasaan konsep dan/atau perubahan perilaku dengan mengutamakan pendekatan deduktif, dimana ciri-ciri model DI: (1) transformasi dan ketrampilan secara langsung; (2) pembelajaran berorientasi pada tujuan tertentu; (3) materi pembelajaran yang telah terstuktur; (4) lingkungan belajar yang telah terstruktur; dan (5) distruktur oleh guru. [6].

Berdasarkan uraian di atas, peneliti tertarik untuk mengadakan penelitian yang berjudul Pengaruh Model Self Regulated Learning terhadap Hasil Belajar Fisika Siswa SMP Negeri 18 Palu.

\section{METODE PENELITIAN}

Penelitian yang digunakan adalah jenis penelitian dengan rancangan eksperimen kuasi (quasi-experimental design).

Desain penelitian yang digunakan yaitu the equivalent pretest-posttest design yaitu menggunakan kelas-kelas yang sudah ada sebagai kelompoknya, dengan memilih kelaskelas yang diperkirakan sama keadaan/kondisinya. Desain penelitian ini digambarkan pada Tabel 1. [7].

\begin{tabular}{cccc}
\multicolumn{4}{c}{ TABEL 1 DESAIN PENELITIAN } \\
\hline Kelompok & Pra tes & Perlakuan & Pascates \\
\hline Eksperimen & $\mathrm{O}_{1}$ & $\mathrm{X}_{1}$ & $\mathrm{O}_{1}$ \\
Kontrol & $\mathrm{O}_{1}$ & & $\mathrm{O}_{1}$
\end{tabular}

Keterangan:

$\mathrm{X}_{1}$ : Model Self Regulated Learning

$\mathrm{O}_{1}$ : Tes awal dan tes akhir

Penelitian dilakukan di SMP Negeri 18 Palu. Populasi dalam penelitian ini adalah seluruh siswa kelas VIII SMP Negeri 18 Palu tahun pelajaran 2015/2016 yang terdiri dari 7 kelas. Sampel dalam penelitian ini adalah kelas VIII A yang berjumlah 20 siswa dan VIII B yang berjumlah 23 siswa. Teknik pengumpulan sampel yang digunakan adalah purposive sampling, yaitu teknik penentuan sampel dengan pertimbangan tertentu.

Instrumen yang digunakan dalam penelitian ini adalah tes pilihan ganda untuk melihat hasil belajar siswa pada mata pelajaran fisika yang telah divalidasi oleh validator ahli. Analisis data dilakukan dengan menganalisis instrumen terlebih dahulu menggunakan uji validitas item dan reliabilitas tes yang kemudian dengan menganalisis data hasil penelitian menggunakan uji normalitas, uji homogenitas dan uji hipotesis.

\section{HASIL DAN PEMBAHASAN}

\section{A. Hasil Penelitian}

Pada penelitian ini proses validasi dilakukan oleh validator ahli. Dimana soal yang telah dibuat dikonsultasikan kepada validator ahli kemudian divalidasi dan direvisi. Validasi yang diuji adalah validasi ahli dan validasi konstruksi. Dari hasil validasi oleh validator ahli, diperoleh 41 soal yang selanjutnya akan dilanjutkan pada tahap uji coba soal. Soal yang telah di validasi oleh ahli kemudian diujicobakan di kelas VIII F SMP Negeri 18 Palu pada tanggal 11 April 2016 yang diikuti oleh 20 orang siswa. Dimana pemilihan kelas ini karena di kelas tersebut telah mempelajari materi getaran dan gelombang.

Adapun instrumen yang diujikan terdiri atas 41 item soal. Uji coba dilakukan dengan tujuan untuk mengetahui validitas, reliabilitas, daya pembeda dan tingkat kesulitan dari instrumen tersebut.

Hasil Uji coba yang telah di uji validitas, reliabilitas, daya pembeda dan tingkat kesulitannya diperoleh 22 instrumen yang layak digunakan dan 3 soal yang divalidasi yaitu soal no 3, 7 dan 21 dimana soal tersebut telah memenuhi validitas dan reliabilitas namun daya pembeda kurang. Instrumen tersebut dapat digunakan dengan melakukan revisi seperlunya yaitu dengan memperjelas maksud soal. Adapun jumlah instrumen yang digunakan dalam penelitian ini sebanyak 22 butir soal.

Data preetest terdiri dari kelas eksperimen dan kelas kontrol yang masing- masing berjumlah 20 siswa dan 23 siswa. Hasil pengolahan data preetest dan posttest untuk masing-masing kelas, yaitu kelas eksperimen dan kelas kontrol, diperoleh nilai maksimum, nilai minimum, nilai rata-rata dan simpangan baku seperti terlihat pada Tabel 2. 
TABEL 2 DESKRIPSI SKOR TES HASIL BELAJAR FISIKA UNTUK KELAS EKSPERIMEN DAN KELAS KONTROL

\begin{tabular}{lcccc}
\hline \multirow{2}{*}{ Uraian } & Preetest & \multicolumn{3}{c}{ Posttest } \\
\cline { 2 - 5 } & Eksperimen & Kontrol & Eksperimen & Kontrol \\
\hline $\begin{array}{l}\text { Sampel } \\
(\mathrm{n})\end{array}$ & 20 & 23 & 20 & 23 \\
$\begin{array}{l}\text { Nilai } \\
\text { maksimum }\end{array}$ & 13 & 12 & 19 & 17 \\
$\begin{array}{l}\text { Nilai } \\
\text { minimum }\end{array}$ & 3 & 2 & 8 & 6 \\
$\begin{array}{l}\text { Skor rata- } \\
\text { rata }\end{array}$ & 7,20 & 6,54 & 13,30 & 10,50 \\
$\begin{array}{l}\text { Standar } \\
\text { deviasi }\end{array}$ & 2,86 & 3,18 & 3,52 & 2,96 \\
\hline
\end{tabular}

Uji normalitas pada penelitian ini menggunakan uji Chi-kuadrat dengan kriteria penerimaan $\mathrm{X}^{2}$ Hitung $<\mathrm{X}^{2}$ tabel, taraf signifikansi a $=0,05$ dan derajat kebebasan $\mathrm{dk}=\mathrm{k}-3$. Berdasarkan hasil perhitungan untuk posttest nilai $\chi^{2}$ hitung untuk ke las eksperimen adalah sebesar 2,82 dan untuk kelas kontrol sebesar 4,53 dengan $\chi^{2}$ tabel sebesar 7,81. Data tersebut disajikan pada tabel 3 .

TABEL 3 HASIL UJI NORMALITAS POSTTEST KELAS EKSPERIMEN DAN KELAS KONTROL

\begin{tabular}{|c|c|c|c|c|}
\hline \multirow[b]{2}{*}{ No. } & \multirow[b]{2}{*}{ Kelas } & \multicolumn{2}{|r|}{ Nilai } & \multirow[b]{2}{*}{ Keputusan } \\
\hline & & $\begin{array}{l}\text { Nilai } \\
X^{2} \text { Hitung }\end{array}$ & $\begin{array}{l}X^{2} \quad \text { Tabel } \\
(a= \\
0,05)\end{array}$ & \\
\hline 1 & $\begin{array}{l}\text { Kelas } \\
\text { Eksperimen }\end{array}$ & 0,63 & 7,81 & $\begin{array}{l}\text { Terdistribusi } \\
\text { normal }\end{array}$ \\
\hline 2 & $\begin{array}{l}\text { Kelas } \\
\text { Kontrol }\end{array}$ & 4,53 & 7,81 & $\begin{array}{l}\text { Terdistribusi } \\
\text { normal }\end{array}$ \\
\hline
\end{tabular}

Berdasarkan hasil uji normalitas pada Tabel 3 diketahui nilai $\mathrm{X}^{2}$ Hitung $<\mathrm{X}^{2}$ tabel sehingga dapat disimpulkan keduanya berasal dari populasi yang terdistribusi normal.

Uji homogenitas pada penelitian ini menggunakan uji statistik Fisher (Uji F) dengan taraf signifikansi $a=0,05$. Uji homogenitas dilakukan untuk melihat apakah data berasal dari varians yang sama atau tidak.

TABEL 4 HOMOGENITAS DUA VARIANS TES AKHIR (POSTTEST) KELAS EKPERIMEN DAN KELAS KONTROL.

\begin{tabular}{|c|c|c|c|c|c|}
\hline No. & Kelas & $\begin{array}{l}\text { Nilai } \\
\text { varians }\end{array}$ & $\begin{array}{l}\text { Varians } \\
\text { hitung }\end{array}$ & $\begin{array}{l}\text { Nilai F } \\
\text { table } \\
(a= \\
0,05)\end{array}$ & Keputusan \\
\hline $\begin{array}{l}1 \\
2\end{array}$ & $\begin{array}{l}\text { Kelas VIII A } \\
\text { (Ekperimen) } \\
\text { Kelas VIII B } \\
\text { (Kontrol) }\end{array}$ & $\begin{array}{l}12,38 \\
8,73\end{array}$ & 1,42 & 2,08 & $\begin{array}{l}\text { Kedua } \\
\text { data } \\
\text { homogen }\end{array}$ \\
\hline
\end{tabular}

Berdasarkan hasil uji homogenitas pada Tabel 4 dengan taraf signifikansi $(a=0,05)$, dari data tersebut terlihat bahwa Fhitung lebih kecil dari Ftabel, maka berdasarkan kriteria pengambilan keputusan dapat disimpulkan bahwa tidak terdapat perbedaan varians antara kelas eksperimen dan kelas kontrol atau dengan kata lain varians antara kelas eksperimen dan kelas kontrol adalah sama atau homogen.

Uji hipotesis dilakukan setelah diperoleh bahwa data hasil belajar Antara kelas ekperimen dan kelas kontrol berdistribusi normal dan homogen. Uji ini digunakan untuk memastikan apakah hipotesis yang dilakukan dapat diterima atau tidak. Uji $t$ tersebut diperoleh berdasarkan data tes akhir. hasil dapat dilihat pada Tabel 5 .

TABEL 5 UJI BEDA RATA-RATA (DUA PIHAK) TES AKHIR KELAS EKSPERIMEN DAN KELAS KONTROL

\begin{tabular}{|c|c|c|c|c|c|}
\hline No. & Kelas & $\begin{array}{c}\text { Nilai } \\
\text { rata-rata } \\
(\bar{X})\end{array}$ & $t_{\text {hitung }}$ & $\underset{\text { table }}{\mathrm{t}}$ & Keputusan \\
\hline 1 & $\begin{array}{l}\text { Kelas } \\
\text { Eksperimen }\end{array}$ & 13,30 & \multirow{2}{*}{2,84} & \multirow{2}{*}{2,02} & \multirow{2}{*}{$\begin{array}{c}\mathrm{H}_{1} \\
\text { diterima }\end{array}$} \\
\hline 2 & $\begin{array}{l}\text { Kelas } \\
\text { Kontrol }\end{array}$ & 10,50 & & & \\
\hline
\end{tabular}

Uji t yang digunakan untuk hipotesis ini adalah uji-t dua pihak. Uji ini digunakan untuk memastikan apakah hipotesis yang diajukan dapat diterima atau ditolak.

Kriteria HO diterima jika thitung < ttabel dan $\mathrm{dk}=(\mathrm{n} 1+\mathrm{n} 2-2)=20+23-2=41$ pada taraf nyata $\mathrm{a}=0,05$, untuk harga $\mathrm{t}$ lainnya $\mathrm{H}_{0}$ ditolak. Dari daftar distribusi diperoleh tabel $=$ 2,02 sedangkan dari hasil perhitungan uji-t diperoleh nilai thitung $=2,84$ yang berada di luar daerah penerimaan $\mathrm{H}_{0}$. Hal ini berarti thitung $>$ tabel $=2,84>2,02$; dengan demikian $\mathrm{H}_{0}$ di tolak dalasm taraf nyata $\mathrm{a}=0,05$ dan $\mathrm{H}_{1}$ diterima. Dengan demikian $\mathrm{H}_{0}$ ditolak dan $\mathrm{H}_{1}$ diterima, dan dapat disimpulkan bahwa ada perbedaan rata-rata hasil belajar fisika antara kelompok siswa yang mengikuti Self Regulated Learning dengan model konvensional. Artinya, bahwa Self Regulated Learning mempengaruhi hasil belajar siswa.

\section{B. Pembahasan}

Tes yang digunakan dalam penelitian ini yaitu tes pilihan ganda berjumlah 22 nomor. Dari hasil pengolahan data preetest yang diberikan kepada kelas ekperimen pertama dan kelas ekperimen kedua diperoleh nilai rerata skor masing-masing kelas yaitu kelas ekperimen 7,20 dan rerata skor kelas kontrol yaitu 6,54, dimana diperoleh nilai rerata skor yang tidak berbeda jauh antara kelas ekperimen dan kelas kontrol sehingga dapat dikatakan bahwa kedua kelas tersebut memiliki kemampuan awal yang sama. Selanjutnya dilakukan pembelajaran yang berbeda di kedua kelas tersebut dengan menggunakan model pembelajaran yang berbeda. Dimana pada kelas ekperimen digunakan model self regulated learning dan untuk kelas kontrol digunakan model pembelajaran konvensional. 
Hasil analisis posttest menunjukkan bahwa perolehan nilai rata-rata untuk kelas ekperimen adalah 13,30 dan untuk kelas kontrol diperoleh nilai rata-rata yaitu 10,50 . Data posttest berdistribusi normal dan memiliki varians yang homogen, kemudian dilakukan uji hipotesis (menggunakan uji dua pihak) dan didapatkan hasi bahwa terdapat perbedaan hasil belajar antara kelas ekperimen dan kelas kontrol.

Hasil uji coba normalitas posttest diperoleh nilai X2 hitung untuk kelas ekperimen yaitu 0,63 dan kelas kontrol yaitu 4,53 dan nilai X2 tabel yaitu 7,81. Hasil tersebut menunjukkan bahwa nilai X2 hitung lebih kecil dari pada nilai X2 tabel sehingga keduanya berasal dari populasi yang terdistribusi normal.

Hasil uji coba homogenitas dua varians posttest kelas ekperimen diperoleh nilai varians 12,38 dan untuk kelas kontrol yaitu 8,73 sedangkan varians hitung yaitu 1,42 , nilai $F$ tabel yaitu 2,08. Berdasarkan hasil tersebut dengan taraf signifikan $(\alpha=0,05)$ diperoleh bahwa Fhitung lebih kecil dari $F_{\text {tabel }}$ maka berdasarkan kriteria pengambilan keputusan dapat disimpulkan bahwa tidak terdapat perbedaan varians antara kelas ekperimen dan kelas kontrol atau dengan kata lain varians antara kelas kontrol dan kelas ekperimen adalah sama atau homogen.

Hasil uji hipotesis yang telah dilakukan diperoleh nilai $x$ rata-rata untuk kelas ekperimen yaitu 13,30 kelas kontrol 10,50 dan untuk ${ }^{t_{\text {hitung }}=}$ ${ }^{2,84}$ dan ${ }^{t_{\text {tabel }}}=2,02$. Karena nilai ${ }^{t_{\text {hitung }}}>t_{\text {tabel }}$, taraf signifikasi ${ }^{\alpha=0,05}$ maka HO ditolak atau H1 diterima.

Hasil belajar fisika kelompok eksperimen yang menggunakan model self regulated learning memiliki hasil belajar lebih tinggi dibandingkan dengan kelas kontrol yang menggunakan model pembelajran konvensional. Karena pada kelas kontrol ini keaktifan guru lebih dominan dibandingkan keaktifan siswa, sehingga siswa hanya mendengarkan dan menulis penjelasan yang diberikan oleh guru. Sedangkan pada kelas eksperimen, diberikan pembelajaran dengan model self regulated learning. Hal ini disebabkan karena dengan menggunakan model self regulated learning siswa akan dituntut untuk lebih aktif sedangkan guru hanya bertindak sebagai fasilitator yang membantu siswa jika mendapat kesulitan saat pembelajaran berlangsung.

Hal lain yang menyebabkan hasil belajar fisika yang menggunakan model self regulated learning lebih tinggi yaitu prinsip model pembelajaran ini adalah adanya keleluasan dalam menegelolah pembelajaran yang terintegrasi dalam fase-fase pembelajarannya.
Tahap-tahap model self regulated learning yang digunakan pada kelas ekperimen terdiri dari 7 fase yaitu analyze, plan implement, implement, comprehend, problem solving, evaluate dan modify.

Fase pertama, siswa antusias menyampaikan pengetahuan yang dimilikinya, baik pengetahuan mengenai materi sebelumnya maupun materi yang akan dipelajari. Fase Kedua, siswa mencari kelompok belajar dan membagi tugas kepada anggota kelompoknya untuk mencari informasi terkait dengan LKS yang telah dibagikan oleh guru. Pada fase ini setiap kelompok berkompetisi untuk mengumpulkan point. Fase ketiga, siswa mencatat hasil dari pengumpulan informasi baik melalui praktikum maupun informasi yang diperoleh dari berbagai sumber terkait masalah-masalah yang terdapat pada LKS yang telah diberikan.

Fase keempat, Siswa mencatat hal-hal yang dianggap penting dan mencatat permasalahan yang dianggap sulit. Fase kelima, perwakilan dari kelompok mempresentasikan hasil diskusi, siswa lain mengajukan pertanyaan yang masih kurang dimengerti kepada kelompok lain maupun kepada guru. Pada tahap ini, pengetahuan siswa akan terlihat karena siswa tersebut akan menyampaikan pengetahuan yang mereka miliki baik pengetahuan yang diperoleh dari buku maupun pengalaman mereka.

Fase keenam yaitu, siswa akan mencermati kembali dan merenungkan kesalahan-kesalahan yang dialami dalam menyelesaikan masalah, memperbaiki konsep-konsep yang masih salah menjadi benar sesuai dengan penjelasan teman maupun guru. Fase ketujuh siswa antusias dalam menyampaikan kesimpulan selama mengikuti pembelajaran dan untusk memberikan motivasi belajar siswa, guru memberikan penghargaan berupa pujian dan hadiah kepada siswa. [8].

Pembelajaran konvensional (model pembelajaranan langsung) umumnya menggunakan metode ceramah, dalam hal ini guru berperan aktif dalam proses pembelajaran. Dalam hal ini siswa hanya sebagai pendengar saja. Proses pembelajaran berlangsung menoton dimana guru hanya menjelaskan, memberikan contoh soal dan memberikan latihan. Sehingga proses pembelajaran seperti ini akan menumbuhkan rasa jenuh dalam diri siswa sehingga berakibat tidak suka terhadap mata pelajaran yang bersangkutan [9].

Hasil yang diperoleh pada penelitian ini menunjukkan bahwa hasil belajar fisika siswa yang diajarkan model self regulated learning lebih tinggi dibandingkan dengan hasil belajar fisika siswa yang diajarkan dengan model pembelajaran konvensional. Hasil ini didukung 
oleh Penelitian sebelumnya yaitu siswa yang diajarkan dengan model self regulated learning memperoleh hasil belajar lebih tinggi dibandingkan dengan siswa yang diajarkan dengan model pembelajaran konvensional. [10].

Penelitian ini memiliki kesamaan dengan penelitian sebelumnya, yaitu pada kelas ekperimen menggunakan model self regulated learning dan pada kelas kontrol menggunakan model pembelajaran konvensional. Hasil yang didapatkan pada tes akhir pada kelas ekperimen lebih tinggi dibandingkan pada tes akhir di kelas kontrol. Sehingga memiliki kesimpulan yang sama bahwa terdapat pengaruh model self regulated learning terhadap hasil belajar fisika siswa. Selain memiliki kesamaan, pada penelitian ini dengan penelitian sebelumnya terdapat perbedaan yaitu pada penelitian ini setiap kelompok berkompetisi untuk mengumpulkan point disetiap pertemuan untuk memberikan motivasi belajar pada siswa. Dan pada akhir pertemuan di berikan penghargaan berupa pujian dan hadiah.

Proses belajar mengajar di kelas ekperimen dan kelas kontrol sebenarnya mempunyai tujuan pembelajaran yang sama yaitu membuat siswa lebih mengerti tentang pelajaran yang diberikan oleh guru. Kedua kelas tersebut memiliki hasil belajar lebih tinggi setelah diterapkan model pembelajaran. Akan tetapi selain kesamaan, kedua kelas tersebut terdapat perbedaan yaitu di dalam self regulated learning akan menimbulkan keaktifan siswa, motivasi belajar, kerja sama dan meningkatkan kreativitas dalam belajar sehingga siswa mendapat kesempatan untuk menemukan dan menetapkan ide mereka sendiri.sedangkan pada kelas kontrol siswa cenderung lebih pasif. Perbedaan tersebut menunjukkan adanya pengaruh model pembelajaran yang digunakan pada kelas eksperimen dan kelas eksperimen kontrol.

\section{KESIMPULAN DAN SARAN}

Berdasarkan hasil analisis uji hipotesis diperoleh bahwa ada perbedaan hasil belajar fisika antara kelompok yang menggunakan Self Regulated Learning dengan kelompok yang menggunakan model pembelajaran konvensional pada siswa kelas VIII SMP Negeri 18 Palu. Hal ini dapat dilihat dari rerata skor preetest kelas eksperimen adalah 7,10 dan rerata skor posttest 13,30 , untuk kelas kontrol diperoleh rerata skor preetest 6,54 dan untuk rerata skor posttest adalah 10,50. Berdasarkan analisis uji hipotesis diperoleh thitung $>$ tabel atau
$2,84>2,02$ atau $\mathrm{H}_{0}$ ditolak dan $\mathrm{H}_{1}$ diterima, yang berarti ada perbedaan hasil belajar fisika antara kelompok yang menggunakan Self Regulated Learning dengan kelompok yang menggunakan model pembelajaran konvensional.

Berdasarkan kesimpulan ada beberapa saran yang dapat dikemukakan: (1) Diharapkan dalam proses pembelajaran Fisika, guru dapat menggunakan guru fisika kiranya dapat mempertimbangkan Self Regulated Learning sebagai salah satu alternatif dalam usaha untuk meningkatkan hasil belajar siswa pada umunya hasil belajar fisika pada khususnya. (2) Kepada mahasiswa khususnya program studi Fisika dapat mencoba menerapkan model Self Regulated Learning pada penelitian mereka dengan materi yang berbeda untuk mengetahui pengaruh model ini dalam pembelajaran Fisika.

\section{DAFTAR PUSTAKA}

[1] Merlin (2015). Perbandingan hasil belajar fisika antara model pembelajaran self regulated learning (SRL) dengan model pembelajaran Problem based learning (PBL) pada siswa kelas XI SMA Negeri 4 Palu. Skripsi Universitas Tadulako Palu: tidak diterbitkan.

[2] Slameto. (2010). Belajar dan Faktor-Faktor yang Mempengaruhi. Jakarta: Rineka Cipta.

[3] Fasikhah, Siti Suminarti, dan Fatimah, Siti. (2013). Self-Regulated Learning (SRL) dalam Meningkatkan Prestasi Akademik pada Mahasiswa. JIPT.4, (8) , 7180.

[4] Nugroho, (2003). Model Pengembangan Self Regulated Learning pada siswa sekolah favorit Semarang. Tes is Magister pada Fakultas Pascasarjana Psikologi Universitas Indonesia. Jakarta: tidak diterbitkan.

[5] Sofiyah. (2010). Pengaruh Model Pembelajaran Langsung (Direct Instruction) Terhadap Hasil Belajar Fisika Siswa. Skripsi Universitas Islam Negeri Syarif Hidayatullah. Jakarta: tidak diterbitkan.

[6] Kholik, M. (2011). Metode Pembelajaran Konvensional. [Online].

Tersedia:http://muhammadkholik.wordpress.com Oktober 2016].

[7] Sugiono (2014). Metode Penelitian Pendidikan. Bandung: Alvabeta.

[8] Elza, Pt. Y. V. G (2015). Pengaruh Model Self Regulated Learning (SRL) Terhadap Pengetahuan Metakognitif IPA Pada Siswa Kelas IV Semester II Di Gugus Kecamatan Busungbiu Tahun Pelajaran 2014/2015. E- Journal PGSD Universitas Pendidikan Ganesha, Vol 3.

[9] Mujiati (2012). Perbedaan Hasil Belajar Fisika Antara Penerapan Model Pembelajaran Kooperatif Tipe Artikulasi dengan Pembelajaran Konvensional pada Siswa Kelas VIII SMP Negeri 14 Palu. Skripsi Universitas Tadulako Palu : tidak diterbitkan.

[10] Dwicky, Dw. MP. (2015). Pengaruh Model Self Regulated Learning (SRL) Terhadap Sikap IImiah dan Hasil Belajar IPA Siswa Kelas IV Tahun Pelajaran 2014/2015 Di gugus XIII Kecamatan Buleleng. E- Journal PGSD Universitas Pendidikan Ganesha, Vol 3 